\title{
Certain Aspects of Accounts Receivable and Payable Analysis
}

\author{
Elene Kharabadze \\ Professor \\ Ivane Javakhishvili Tbilisi StateUniversity, Georgia \\ Merab Jikia \\ Associated Professor \\ Ivane Javakhishvili Tbilisi StateUniversity, Georgia
}

\begin{abstract}
One of the primary ways to improve sales and to develop business is to increase credit sales, in other words, to extend the terms of payment. This, in effect, increases the risk on nonpayment, which represents accounting loss that could materialize in bankruptcy. Therefore, it is necessary to develop effective system of accounts receivable management, which mainly depends on its current analysis and prognosis. Account receivable analysis should focus on the following aspects: evaluate the nature of receivable, predict the probable amount of receivable, implement sound credit policy, determine aging of receivable and develop matching mechanism between accounts receivable and accounts payable. On one hand, lenient credit policy creates more work for the firm because it has to analyze its customers, conduct aging and, subsequently, increase firms' expenses. However, strict credit policy has its drawbacks as well. The primary disadvantage of strict credit policy is the loss of customers, which will also reduce revenue. The following conclusion was formed: the increase of turnover period of accounts receivable and inventory and the reduction of turnover period of accounts payable causes the reduction of cash and cash equivalents. Furthermore, the reduction of the turnover period of accounts payable and inventory and the increase of turnover period of accounts payable causes the increase of cash and cash equivalents.
\end{abstract}

Keywords: Accounting, Accounts Receivable, Accounts Payable, Credit Policy, Liquidity Management

One of the main ways to increase sales and further development of business is to sell with a deferred payment, i.e. to extend to the buyers the periods of payment, while this, in its turn increases a risk of return of the money sources in a timely manner, that originates a damage and causes loss of solvency. All this makes it necessary to develop an efficient system for controlling the Accounts Receivable, where the current and predictive analysis will be the main component

The development of a system for the analysis of accounts receivable directly depends on the strategic objectives of the enterprise development, which determines a nature of the enterprise's activities with participation of its employees, the credit policy, and the approach to assessing contributions to debt repayment.

The following factors have an impact on the accounts receivable of an enterprise:

- Volume of sales on terms of deferred payment, which in turn will increases the amount of debt;

- Terms of payment between the client and the Buyers. As preferential conditions have the buyers in payments (prolongation of periods of payment, decrease of demand of assessment of reliability, etc.) as higher the balances of the accounts receivable; 
- Penalty sanctions policy. As active the enterprise is in applying the penalties for the accounts receivable, as lower the balances and higher the "degree" of the accounts receivable

- Payment discipline of buyers. The objective reasons, which determine the payment discipline of buyers and customers, may include the overall economic state of those sectors to which they belong, while the subjective reasons are determined by the terms of the bank credits and the measures taken by the enterprise to cover the accounts receivable;

- Quality of analysis of the accounts receivable and a consistent application of the results thereof

When conducting the analysis of enterprise's activity on a satisfactory level, the information regarding the following factors should be available:

- Amount of the accounts receivable and their structure by dates of origination;

- Volume of the delayed accounts receivable as well as identified debtors, delay of payments from which creates problems to the enterprise's current solvency;

- Risks of delayed payments as well as possible losses

Availability of such information makes it possible to assess reliability of the accounts receivable, develop the ways of its predictive analysis, provide a justification of a final version of a rational policy having been chosen for controlling settlements with buyers. This will create preconditions for transition from a passive control of the accounts receivable (that is mainly lowered to accounting the information on a com[position and structure of a debt) to the policy of active control, which implies a targeted impact on the terms and conditions of the credits provided to the buyers

The main purpose of analysis of the accounts receivable is introduction and justification of the buyer's crediting policy, which should be directed to acceleration of payments and reduction of the non-payment risks. Moreover, the crediting policy should facilitate to stimulation of sales.

The basic tasks of the analysis are as follows:

- Assessment of a state of the account receivable, its composition and structure;

- Formation of the analytical information, which will enable us to predict the expected values of the accounts receivable

- Development and analysis of the credit policy with substantiation of the credit limits and terms of the credits provided to certain buyers

- Determination of a fair value of the accounts receivable in a variable environment of purchasing ability of cash resources

- Control of ratios of the terms and conditions of the credits issued to buyers and the commercial credits received from suppliers

In the most generalized form, both the structure and size of the account receivable may be analyzed based on the balance data. For the purposes of internal analysis, application of the managerial accounting data seems to be necessary. 
To analyze the account receivable, an index of a weighted share (\%) of the debts in a total volume of the working assets, is used:

Share of the account receivable on a total volume of the working assets

\section{Account receivable}

$=$
X 100

Current assets

A share of the diubtdul debts in the total accounts receivable (\%)

Share of the doubtful debt

\section{Doubtful account receivable}

\section{Accounts receivable} X 100

This is the indicatior which characterizes the rate of indebtedness. The trend of increase thereof confirms a reduction of the liquidity level. This indicator is used in the course of internal debt analysis

Share of the account receivable

Account receivable

$\mathbf{X} 100$

\section{Sales volume}

The above mentioned indicator prov odes the information of how many $\%$ of unsold products come on each P.U. of sales

Account Receivable Repayment Period (\%)

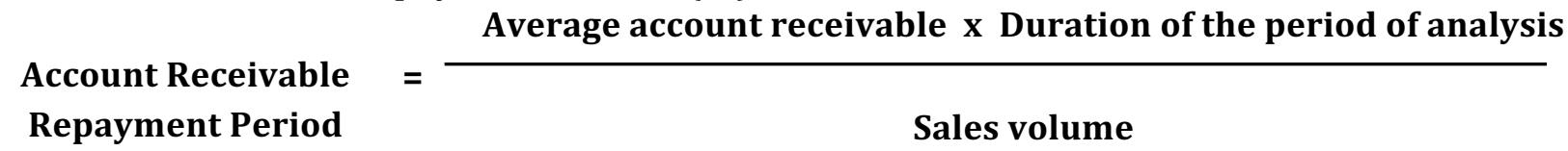

Based on the above indicator, we may assess, in which average period the debt may be repaud At the same time, it could not be correct to make a general indication, which term of delay in payments can be belonged to the doubtful debts. For the purposes of internal analyses, a company decides this issue at its own discretion, with taking into consideration the current situation and the applied practice of payments

An external analyst holds just the reporting information, and therefore he/she relies on the accounts receivable decrypted data which are attached to the annual financial statements and their explanatory notes. Besides, it should be noted also that the information characterizing a state of accounts receivable in Georgia, is drawn comparable less attention than it is envisaged under the international practice

In the world practice, one of the aspects of free availability of the information on the state of accounts receivable is a characterization of essential risks associated with specific debtors. Absence of such information in the financial statements of the Georgian enterprises largely reduces its transparency and, obviously, the reliability of the results of the analysis of financial position

Rather an effective tool for analyzing the account receivable is a study of its composition by terms of repayment. Such an analysis provides an opportunity to assess the payment discipline of buyers and at the same time, the attemots of the enterprise directed to repayment of its debts

A known fact is that increase of the accounts receivable causes extra costs, which are associated to certain works conducted with debtors (communication costs, travel expenses, 
etc.). Besides, the losses caused by dead debts are increases also. In addition to the above, increase of the accounts receivable as a result of postponing the deadlines of payment, in its turn, causes the losses associated to changes in the purchasing power of the money

A strong credit policy, which is directed to shortening the payment terms and excluding the facts of non-payment has its negative outcomes as well. In such cases, the accounts receivable and correspondingly, the costs, will be minimum for their funding. Moreover, a string credit policy may cause a loss of clients, that, in its turn, will reduce the volumes of sales

Thus, depending upon the strategy selected by an enterprise (increase of volumes and widening the business or preservation of the already formed volumes of operations, which are mainly directed to and relied on a circles of high reputable clients) the credit policy and consequently, an advisability of the analysis of the accounts receivable, will be variable

As known, duration of a stage implies a period from receive of materials for processing till issuance of a ready-made product If an enterprise produces uniform products, than, by turnover of the "incomplete production" account (through which a cost of the issued products is determined) a duration of a given stage of the operational cycle will be assessed

Turnover of resources within the scopes of one operational cycle, is given in the following scheme:

\section{Scheme 1}

Stages of the o[errational cvycle of an industrial enterprise

\begin{tabular}{|c|c|c|c|c|}
\hline $\begin{array}{c}\text { Advances issued to } \\
\text { suppliers }\end{array}$ & $\begin{array}{c}\text { Storage of } \\
\text { stocks }\end{array}$ & Production & $\begin{array}{c}\text { Storage of the } \\
\text { ready-made } \\
\text { products }\end{array}$ & $\begin{array}{c}\text { Repayment of } \\
\text { the debts }\end{array}$ \\
\hline 0 & 1 & 2 & 3 & 4 \\
\hline
\end{tabular}

As the scheme shows, section $0-1$ corresponds to an average time during which the money sources of the enterprise are at the supplies in a form of advance payments; Section $1-2$ indicates the terms of storage of the stocks from the moment of delivery until transfer to the production; Section $2-3$ is a duration of the production cycle; Section $3-4$ is a time of storage of the ready-made products, while Section $4-5$ is an average term od repayment of the debt

When conducting the analysis of securing the operational cycle by the sources of funding, assessment of the terms of the accounts payable $\left(\mathrm{T}_{\mathrm{kd}}\right)$ is of a special importance. In practice and methodological literature, various modifications are used for calculation of the aforementioned indicators:

Table 1:

Calculation of Terms of Repayment of Accounts Payable

\begin{tabular}{|c|c|c|}
\hline № & Basis of calculation & Formula of calculation \\
\hline 1 & Return n (V) & $\mathbf{T}_{\mathrm{kd}}=\left(\mathbf{K d}^{*} \mathbf{x D}^{* *}\right) / \mathbf{V}$ \\
\hline 2 & Cost (C) & $\mathrm{T}_{\mathrm{kd}}=(\mathrm{KdxD}) / \mathrm{C}$ \\
\hline 3 & Purchasing Value (S) & $T_{k d}=(K d x D) / S$ \\
\hline 4 & Amopunt opaid within the period (I) & $T_{\mathrm{kd}}=(\mathrm{KdxD}) / \Pi$ \\
\hline
\end{tabular}

${ }^{*} \mathbf{K d}$ - Amount of the accounts payable

**D - Duration of the period of analysis 
This method of calculation on the basizs of return, is the most common approach gto theanalysis of turnover of the accounts payable. Therefore, this is the least suitable for calculating the financial cycle.

Compared to the previous method, it is more appropriate to use a calculation method on the cost basis. It is especially justified in cases of conducting the external analysis when it is difficult to obtain additional information for more accurate calculation.

The $3^{\text {rd }}$ and $4^{\text {th }}$ versions of the calculation are the most accurate as they rely on the data of turnover of the accounts payable. Version 3 envisages application of the credit turnover of the accounts payable in a form of the originated liabilities, while Version 4 deals with the debit turnovers during the period of analysis, by the amounts paid during this period. Existence of demands on the sources of funding the operational cycles, may be represented graphically as follows:

\section{Scheme 2}

Relationship between operating and financial cycles of the enterprise Operating Cycle

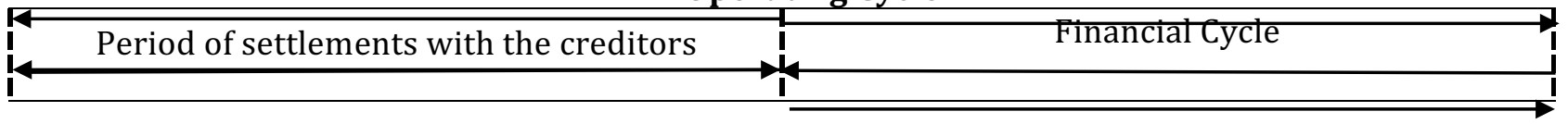

Excess of duration of the operating cycle (OC) over the term of repayment of the accounts pzahyable $\left(\mathrm{T}_{\mathrm{kd}}\right)$, ibtained a titler of the net operating cycle i.e. ogf A financial cycle (FC)

$$
\mathbf{F C}=\mathbf{O C}-\mathbf{T}_{\mathbf{k d}} \text { * }
$$

If a duration of the operating cycle exceeds a term of repayment of the depts to the creditors than the enterprise will have a demand on extra sources of funding. Such the sources may be the own money destined at funding the current assets (own working capital) or the borrowed money, which in the most cases are the ones given to the enterprises in a form of the short term bank credits

The longer the operating cycle of the means of creditors - suppliers serve the greater the solvency of the enterprise.

If the enterprise does not use the bank credits and, makes all its best to overcome the problems through its own resources only, then its solvency swill be fully depended on the volumes and terms of the credits issued to he buyers (accounts payable) and, their goodwill. Delay of money flows from one or more major buyers, may create serious financial problems to the enterprise

When developing the credit policy, enterprises should foresee the main rule: conditions for attraction of the credit must correspond to the ones through which the enterprise issues credits. As the account receivable is essentially the credit issued to the buyers, it, with its possibilities(in comparable terms) should be in equilibrium to the conditions of receiving credits from the suppliers. In case of necessity of funding the accounts receivable by the bank credits, a relevant compensation must be envisaged

Therefore, the main indicators of the solvency of the enterprise are the duration of operating cycle and the size of the net operating cycle (financial cycle).

Based on the correlation between and dynamics of the above mentioned indicators, a demand on the sources of funding the operating cycle can be determined, which is necessary for 
assessment of stability of the enterprise. A trend of increase of the financial cycle confirms an origination of increasing demand on funding in the enterprise

It is possible also to organize the operating cycle and the procedure of settlements with the creditors in such a manner that a period of repayment of the accounts payable be longer than a period of the money turnover in the enterprise. In such a case, there exists no demand on servicing the operating cycle of the own capital. This situation has more theoretical importance than practical, for the industrial and civil engineering companies, while for the companies involved in the branches of trade and service, such the possibilities are rather realistic

Let us consider the example of a trade organization that sells goods only for cash and, has the credit from the supplies with 45-day term of repayment, while an average period of storage of the goods is 30 days. The given operating cycle can be introduced schematically as follows:

\section{Scheme 3 \\ Situation when the term of settlement with the creditors exceeds the operational cycle}

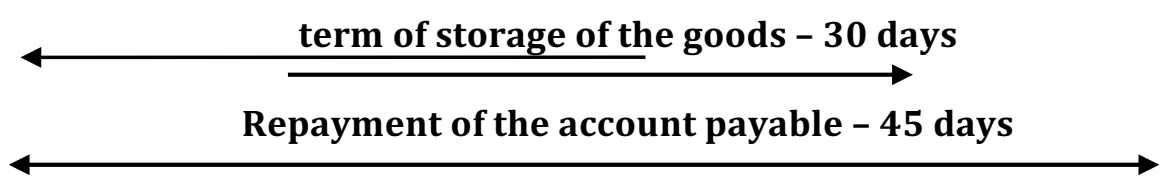

As seen, a state of the trading organization is so stable that in condition of 30-day term of capital turnover it is able to make settlement with the creditors after 45 days, i.e. the company may use the suppliers capital during 15 days after the end of the operating cycle

Up today, the discussions on the analysis of turnover of the current assets, touch only that part of the assets, which are directly involved in the operating cycle. Besides, we must not forget that an enterprise in its ordinary daily operations uses an important part of the working capital, which does not belong directly to the operating cycle. As known, a final stage of the operating cycle is receipt of money from the buyers. This money has its period of turnover, i.e. the period during which it is deposited on the bank accounts of the enterprise. Thus, a total turnover of the money sources invested in the current assets of the enterprise will be higher than the operating cycle.

Amount of changes of the money during the period of analysis depends directly upon a speed of turnover of the current assets, as well as upon the duration of the term of settlements with creditors.

Considering all the above stated, we can formulate the following conclusion: Any increase of period of turnover, i.e. increase of those current assets in the balance such as the reserves and the accounts receivable, as well as acceleration of settlements with the creditors (reduction of residuals in the balance) are accompanied by outflow of the money and vice versa, acceleration of turnover of the reserves and accounts receivable, i.e. other elements of turnover of the current assets in settlements (reduction of residuals in the balance), in line with increase of the period o repayment of the liabilities to the creditors, causes inflow of the money 